Education, Psychology, and Sociology.

\title{
Masalah Berpasang-Pasangan dalam Kalangan Pelajar Sekolah
}

\author{
Mohd Razimi Husin ${ }^{1}$, Nur Syahira Sofia Mohd Suhairi ${ }^{2}$, Wan NoraqilahWan Aziz ${ }^{3}$, Wan \\ Muhammad Aiman Zukifli ${ }^{4}$, Norul Alia Ismail ${ }^{5}$, Ernadia Hazlin Mohd Hata ${ }^{5}$, Sharifah \\ Rashidah Syed Mohmad Rashid ${ }^{2}$, Venusha Segar ${ }^{2}$, Faradyna Shafeena Effendy ${ }^{2}$
}

${ }^{1}$ Faculty of Human Development, Universitas Pendidikan Sultan Idris, Malaysia.

${ }^{2}$ Program of ISMP Biologi, Universitas Pendidikan Sultan Idris, Malaysia.

${ }^{3}$ Program of TESL, Universitas Pendidikan Sultan Idris, Malaysia.

${ }^{4}$ Program of Pendidikan Jasmani, Universitas Pendidikan Sultan Idris, Malaysia.

${ }^{5}$ Program of ISMP Kimia, Universitas Pendidikan Sultan Idris, Malaysia.

Article History

Received:

11.02.2020

Revised:

11.03.2020

Accepted:

11.04 .2020

*Corresponding Author:

Mohd Razimi Husin

Email:

razimi@fpm.upsi.edu.my

This is an open access article, licensed under: $\mathrm{CC}-\mathrm{BY}-\mathrm{SA}$
Abstrak: Masalah berpasang-pasangan kebanyakkan melibatkan remaja yang berusia 16 tahun ke atas yang mana pada usia ini remaja berada pada peringkat akhir remaja. Konflik-konflik yang berlaku dalam fasa ini adalah sangat penting kerana ianya mampu mempengaruhi masa depan seseorang tatkala meningkat dewasa. Masalah berdua-duaan atau berpasang-pasangan adalah masalah yang sangat sukar di atas di mana-mana sekolah sekalipun. Objektif kajian iaitu untuk mengkaji faktor-faktor, kesan masalah, dan langkah-langkah untuk mengatasi masalah berdua-duan dalam kalangan pelajar sekolah. Pengkaji telah menggunakan beberapa kaedah kajian iaitu termasuklah kaedah temubual dan kaedah perpustakaan bagi mendapatkan maklumat mengenai berpasangan atau berdua-duaan dalam kalangan pelajar sekolah. Kesimpulannya, masalah berdua-duaan atau berpasang-pasangan di sekolah semamamngnya berada di tahap yang membimbangkan. Ini adalah kerana masalah ini merupakan suatu masalah yang tiada satu sekolah pun terlepas daripadanya termasuklah sekolah menengah agama. Sekiranya perkara ini tidak dikawal ianya akan membawa kepada permasalahan gejala sosial remaja seperti lari rumah, buang anak, keruntuhan akhlak, dan lemah dalam pelajaran. Masyarakat, media massa, dan ibu bapa memainkan peranan penting dalam mengatasi masalah ini.

Kata Kunci: Berpasang-Pasangan, Pelajar Sekolah, Remaja

\section{Problem of Couple among School Students}

Abstract: The problem of couple mostly involves adolescents aged 16 years and over which at this age teens are in the final rank of adolescents. The conflicts that apply in this phase are very important because they are able to influence one's future as they mature. The problem of being together or in pairs is a very difficult problem even in any school. The objective of the study is to examine the factors, the impression of a problem, and the steps to overcome problems together in school students. The reviewer has used a number of study methods including the social and library methods to obtain information about pairs or partners in school students. In conclusion, the problem of being alone or in pairs at school is at a very confusing stage. This is because this problem is a problem that not even one school apart from including a religious secondary school. If this case is not guarded it will lead to problems of adolescent social symptoms such as running away, throwing away children, moral collapse, and weakness in learning. Society, mass media, and mother and father play an important role in overcoming this problem.

Keywords: Couple, Student, Teenagers. 


\section{Pendahuluan}

Peringkat remaja bermula sekitar umur sebelas tahun dan berakhir lebih kurang sepuluh tahun berikutnya iaitu pada awal 20-an. Masalah berpasang-pasangan ini kebanyakkan melibatkan remaja yang berusia 16 tahun ke atas yang mana pada usia ini remaja berada pada peringkat akhir remaja. Di Malaysia, majoriti remaja pada peringkat ini berada di sekolah menengah. Namun tidak dinafikan bahawa pelajar menengah rendah bermula dari tingkatan dua sudahpun terlibat dalam masalah ini. Remaja ialah individu yang telah mengalami baligh yang disebabkan perubahan hormon. Kadar perubahan hormon ini menyebabkan berlakunya perkembangan terhadap diri remaja dari segi fizikal, kognitif, dan psikososial. Perkembangan inilah yang menyebabkan berlakunya perubahan dalam diri remaja yang mana pada peringkat ini kesemua aspek yang berlaku di sekilingnya mempengaruhi diri remaja.

Perkembangan fizikal adalah perkembangan dari aspek berat badan, bentuk tubuh, dan ketinggian. Bagi pelajar yang berada di menengah rendah perubahan fizikal akan berlaku dengan agak ketara dengan ketinggian dan berat badan akan meningkat secara aktif. Bagi remaja lelaki, perubahan akan berlaku di bahagian dada, bahu, dan juga otot-otot badan. Manakala bagi remaja perempuan, perubahan fizikal akan lebih ketara kerana punggung akan melebar dan lemak akan mula berkumpul di dada, punggung, peha, dan pinggang. Selepas baligh, perubahan tubuh badan akan mula berkurangan. Pusingan haid bagi remaja perempuan dan pengeluaran sperma bagi remaja lelaki akan menjadikan sistem pembiakan mereka lebih stabil. Tubuh badan mereka juga adalah hampir sama dengan saiz dan bentuk tubuh orang dewasa. Namun bagi pelajar di menengah atas, mereka telah pun mencapai had maksimum ketinggian. Kebanyakkan remaja akan berasa bimbang akan ketinggian, berat badan dan bentuk tubuh mereka. Remaja perempuan lebih risau mengaai hal-hal ini berbanding remaja lelaki. Remaja lelaki lebih mengutamakan bentuk badan yang tegap, kemahiran, dan kekuatan.

Dari aspek kognitif, remaja akan mampu berfikir perkara-perara abstrak dan melakukan penaakulan saintifik. Namun, otak remaja masih melalui proses pertumbuhan dan perkembangan. Perkara ini menyebabkan remaja lebih cenderung membuat pertimbangan yang tidak tepat, tidak matang dan tidak munasabah. Menurut pandangan Piaget [1], bagi peringkat awal remaja mereka berupaya menyelesaikan masalah konkrit dan abstrak, mengkaji perasaan dan pemikiran sendiri, menyelesaikan prinsip-prinsip dan membentuk hipotesis-hipotesis dalam menyelesaikan masalahan skema atau struktur mental akan bertambah. Bagi peringkat akhir remaja pula mereka akan mula berlumba-lumba untuk mendapatkan kecemerlangan akademik dan seterusnya bercita-cita mendapatkan pekerjaan yang paling sesuai untuk diri mereka. Mereka akan bertukar-tukar pendapat dengan orang dewasa bagi mencapai matlamat mereka. Tetapi tidak semua remaja berjaya kerana ada di antara mereka mempunyai keterbatasan mental akibat kecewa dalam percintaan, masalah keluarga dan sebagainya.

Perkembangan psikososial menyebabkan remaja mula mencari identiti diri dan pada ketika ini peranan rakan sebaya adalah sangat penting. Pada umur 14 tahun, sebahagian besar remaja lelaki akan mula tertarik dengan remaja perempuan. Mereka akan mula mencuba berkawan dengan remaja perempuan. Remaja lelaki bersifat ekstrovert nampaknya lebih Berjaya memulakan persahabatan dengan remaja perempuan. Pada peringkat ini juga remaja lelaki dan perempuan cuba menuntut kebebasan. Tanda-tanda tuntutan ini kelihatan apabila mereka mula bersungut apabila diberikan tugasan. Remaja juga dikatakan mula membina identiti dan pesonaliti diri. Konflik serta kecelaruan identity yag dihadapi mampu membina personaliti yang berjaya sekira ianya mampu ditangani dengan baik. Pergaulan mereka dengan rakan sebaya juga akan semakin meningkat. Pada tahap ini rakan sebaya merupakan orang yang paling dipercayai dan menjadi ikutan mereka. Pada peringkat akhir remaja, mereka akan belajar untuk bertingkah laku seperti yang diharapkan oleh orang dewasa. Mereka juga mempunyai keinginan untuk mendapatkan penerimaan dan pengenalan daripada ahli kumpulan.

Kesimpulannya, kesemua perubahan dalam diri remaja ini mampu memberi kesan dalam pembinaan identiti dan personaliti diri mereka. Konflik-konflik yang berlaku dalam fasa ini adalah sangat penting kerana ianya mampu mempengaruhi masa depan seseorang tatkala meningkat dewasa. Masalah berdua-duaan atau berpasang-pasangan adalah masalah yang sangat sukar di atas di manamana sekolah sekalipun. Ianya merupakan masalah yang berkait rapat dengan fitrah manusia yang mana sekiranya tidak ditangani dengan baik akan merosakkan diri, keluarga, negara serta generasi akan datang. Oleh itu, semua pihak seharusnya memahami keadaan remaja agar tidak terlalu cepat untuk menghukum perbuatan mereka sebaliknya berbincang dengan cara yang terbaik supaya mereka 
mampu menerima teguran serta nasihat dan berfikir sebaiknya mengenai tindakan mereka supaya tidak tersilap langkah di kemudian hari kelak. Kajian ini memiliki objektif iaitu:

1. Untuk mengkaji faktor-faktor berlakunya masalah berdua-duaan di sekolah.

2. Untuk mengetahui kesan maslah berdua-duan dalam kalangan pelajar sekolah.

3. Untuk mengenal pasti langkah-langkah untuk mengatasi masalah berdua-duaan di sekolah.

\section{Sorotan Kajian}

\subsection{Faktor Gejala Couple/Berdua-Duaan}

\subsubsection{Faktor Media Massa}

Media massa memainkan peranan yang penting dalam menyebar dan menyampaikan maklumat dan pendidikan kepada masyarakat terutamanya kepada pelajar. Masa kini, boleh dikatakan setiap rumah dari pelbagai lapisan masyarakat mempunyai kemudahan audio-video seperti televisyen, radio, internet, VCD, DVD, dan komputer. Namun sebaliknya, penyalahgunaan media massa semakin berleluasa dalam kalangan masyarakat terutamanya para pelajar dan media massa ini memberi pengaruh yang negatif terhadap akhlak pelajar [2]. Menurut Tamuri [3] masalah keruntuhan akhlak pelajar pada masa kini adalah berada pada tahap sangat krisis. Ini disebabkan oleh pembentukan watak remaja banyak dipengaruhi oleh media massa. Justeru, kesilapan dalam memilih bentuk hiburan boleh menjadikan manusia ketandusan akhlak dan mudah terikut-ikut dengan budaya luar yang diserapkan dan akan merosakan akhlak dan budaya generasi akan datang.

Terdapat dua kesan yang diperolehi daripada faktor media massa iaitu kesan negatif dan kesan positif. Antara kesan negatif yang diperolehi adalah terlalu mudah untuk melakukan perkara yang tidak berfaedah sebagai contoh daripada televisyen melalui filem atau adegan ganas serta kurang bermoral ditonton golongan pelajar secara berterusan dan berulangkali menyebabkan jenayah bertambah dan akhlak remaja kian rosak. Selain itu, remaja mudah terdedah kepada banyak maklumat yang tidak berfaedah tanpa dipantau oleh ibu dan bapa.

Menurut Sarji [4] pelbagai majalah yang berunsur kurang mendidik pembaca kini terdapat dipasaran juga mempunyai pengaruh dalam perkembangan akhlak remaja. Media cetak dan eletronik banyak menyebarkan fahaman seks yang keliru, pornografi dan pornoaksi, iaitu menyimpang dari budaya dan agama. Akhir sekali, golongan remaja lazimnya mudah terpengaruh dan mengikut hal yang dilihat di sekeliling mereka sebagai contoh bermain aplikasi tiktok, wechat, dan instagram telah mengakibatkan pelajar lalai dalam pelajaran. Melalui aplikasi tiktok mereka membuat video secara pasangan tanpa menjaga batas pergaulan antara bukan muhrim. Menurut Ayub [5] media massa ialah saluran pendidikan tidak formal kepada masyarakat. Di Malaysia, saluran ini telah menyalurkan budaya "permissike" daripada barat.

Kesan positif yang diperolehi adalah memudahkan komunikasi antara satu sama lain. Pelajar mudah mencari kenalan lama yang telah lama tidak berjumpa dengan mengunakan media massa melalui whatsapp, instagram, dan twitter. Selain itu, memudahkan pelajar mencari maklumat tambah melalui internet untuk kegunaan mencari bahan untuk pelajaran. Pengaruh media massa dan hubungannya denga pembentukan akhlak mulia adalah sangat penting dalam membentuk perbuatan manusia dan apa sahaja yang lahir daripada manusia itu sendiri. Kesannya boleh membawa sifat mulia yang ada itu dalam jiwa hendaklah berterusan. Sebenarnya, perbuatan manusia mempunyai hubungan yang erat dengan sifat dan pembawaan yang ada di dalam hatinya menunjukkan bahawa kaedah yang tepat dalam memulihkan tingkah laku manusia dan mewujudkan cara hidup yang sejahtera adalah dengan memulih dan membersihkan jiwa manusia di samping menanamkan nilai akhlak yang mulia.

\subsubsection{Faktor Ibu Bapa}

Kurangnya perhatian daripada ibu bapa juga menyebabkan para pelajar mencari kasih sayang diluar dengan cara bercinta. Seperti yang kita sedia maklum, kasih sayang serta perhatian merupakan keperluan asas yang sangat penting dalam pembentukkan seseorang insan yang bergelar remaja dan sudah semestinya kasih sayang yang ditujukan itu adalah daripada ibu bapa kerana ibu bapa merupakan individu yang paling hampir dengan pelajar. Para pelajar banyak menghabiskan masa mereka dirumah, maka perhatian yang khusus haruslah diberikan terutama sekali apabila mereka meningkat usia remaja. Ibu bapa perlu mengambil tahu dengan siapa anak mereka berkawan serta mengetahui serba sedikit mengenai latar belakang rakan-rakan anak mereka. Malah di usia remaja inilah ibu bapa perlu menjadi rakan dan sahabat kepada anak-anak untuk mendengar masalah dan luahan hati mereka kerana ibu bapalah tempat mereka mengadu. Tambahan lagi, anak-anak yang 
mendapat perhatian secukupnya daripada ibu bapa dapat mengelakkan atau melambatkan anak-anak terlibat dengan gejala bercinta. Ini dapat dibuktikan melalui Yahya \& Jaafar [6] remaja yang tinggal bersama ibu tunggal, bapa tunggal atau dibesarkan oleh nenek dan datuk mereka lebih cepat memulakan hubungan cinta dengan remaja yang berlainan jenis. Sebaliknya, remaja yang menerima perhatian dan kasih sayang daripada ibu dan bapa mereka, lebih cemerlang di bidang akademik, lebih banyak bergaul dengan rakan-rakan sejenis serta lambat melibatkan diri dalam hubungan cinta.

Namun, apabila ibu bapa terlalu sibuk bekerja mencari nafkah di luar, menyebabkan perhatian yang sepatutnya diberikan kepada anak-anak terabai. Jika kita dapat lihat 20 tahun kebelakangan ini, kebanyakkan dalam institusi kekeluargaan yang bekerja adalah bapa, tetapi disebabkan kegawatan ekonomi hari ini mendesak kedua ibu bapa untuk bekerja mencari nafkah. Maka, apabila ibu bapa sibuk bekerja dan kurang memberi perhatian kepada anak-anak menyebabkan anak-anak berasa sunyi. Keadaan ini akan menggangu perkembangan fisiologi anak-anak dimana mereka merasakan bahawa tiada insan yang menyayangi mereka. Apabila anak-anak merasakan perasaan sebegitu dan pada masa yang sama ada rakan yang berlainan jantina dapat memberi perhatian dan mendengar masalah serta luahan hati mereka menyebabkan mereka rasa disayangi. Rakan berlainan jantina yang awalnya hanya bermula dengan rakan biasa untuk meluahkan masalah bertukar menjadi rakan istimewa apabila sering berhubung melalui media sosial dan sebagainya. Keadaan sebeginilah melibatkan pelajar terlibat dan terdedah dengan gejala bercouple dan berdua-duaan.

Berdasarkan teori-teori perkembangan manusia, teori yang berkaitan dengan temubual pengkaji ialah teori perkembangan kognitif menurut Piaget. Perkembangan kognitif menurut Piaget boleh ditakrifkan sebagai teori perkembangan intelektual yang mencerminkan adanya kekuatan antara fungsi biologi \& psikologi. Faktor yang berpengaruh dalam perkembangan kognitif ialah Fizik, kematangan, pengaruh sosial serta proses pengaturan diri yang disebut ekuilibrasi. Isu yang dibicangkan adalah mengenai isu bercinta/bercouple ataupun berdua-duaan dalam kalangan pelajar sekolah. Isu bercinta/bercouple juga mempunyai perkaitan dengan teori kognitif menurut Piaget dimana isu bercinta/bercouple juga melibatkan fungsi biologi dan psikologi. Isu bercinta/bercouple ini juga melibatkan faktor kematangan, pengaruh sosial serta proses pengaturan diri pelajar itu sendiri.

\subsubsection{Faktor Persekitaran}

Persekitaran bagi seseorang pelajar memainkan peranan yang sangat penting. Persekitaran membawa maksud kawasan di sekeliling sesuatu tempat atau kawasan sekitar. Pelajar sekolah sentiasa ingin melakukan perkara yang baharu ataupun yang lebih sesuai adalah mereka ingin mengikut trend yang sedang berlaku di sekeliling mereka.

Rakan sebaya yang sangat mempengaruhi pelajar-pelajar kerana mereka melihat bahawa rakan mereka couple dan mereka juga mahukan itu juga. Perkara itu lihat seperti menyeronokkan mereka kerana ada orang yang sayangi mereka, mereka bolek keluar untuk dating untuk makan sekali dan keluar bersama-sama. Di persekitaran mereka tiada sesiapa yang baik untuk dicontohi. Jika terdapat sesiapa yang baik untuk mereka mencontohi, mereka juga akan menetapkan sasaran mereka untuk menjadikan diri mereka seperti itu juga. Disebabkan tiada contoh yang baik mereka hilang matlamat masa hadapan mereka.

Pelajar-pelajar ini juga kurang mendapat perhatian daripada ibu bapa mereka dan hal ini menyebabkan mereka mencari kasih sayang dari orang luar. Jikalau ibu bapa memberikan perhatian kepada mereka, ibu bapa akan mengawal pergerakan anak-anak mereka dan anak-anak ini juga tidak perlu mencari kasih sayang di tempat yang lain kerana mereka mendapat kasih sayang yang cukup daripada ibu bapa mereka sahaja.

Persekitaran memainkan peranan yang sangat penting dalam masalah berdua-duaan ini. Kesimpulan, remaja yang bergelar pelajar atau mahasiswa tidak akan terlepas dengan terjerumus ke kancah percintaan. Mereka sering kali alpa dengan dunia mereka sendiri. Tanggungjawab yang sepatutnya dipikul sebagai seorang pelajar disia-siakan. Bercinta merupakan suatu yang abstrak yang tidak dapat dinilai dari sudut kontaknya dan maksudnya amat mendalam. Dalam sibuk mengejar cinta, cita-cita atau matlamat adalah pilihan utama.

Apa yang cuba diketengahkan dalam tulisan ini ialah sebahagian daripada kerosakan yang terdapat dalam alam persekitaran kita dan khususnya ruang di mana kita berada pada hari ini. sama ada suka atau tidak, apa yang dapat kita saksikan pada hari ini, remaja sudah tergiur dek keenakkan hidangan dunia sehingga tidak sedar ianya membahayakan. Salah satu permasalahan yang sering kita temui dan sudah menjadi suatu 'trend' bagi golongan remaja ialah 'percintaan'. Telah banyak kisah yang 
terdengar dibalik kalimah indah ini termasuklah keributan, keresahan, kerosakan, dan kebejatan masyarakat yang timbul sehingga kadang kala ada yang rela nyawanya melayang atau rela akidahnya tergadai hanya kerana kalimah nan indah ini. Apa yang jelas dan pasti fenomena percintaan ini banyak kita jumpai dalam masyarakat kita.

Teori yang boleh dikaitkan dengan faktor-faktor tersebut adalah teori keperluan Abraham Maslow terutamanya tentang keperluan sosial dan kasih sayang dimana untuk mendapatkan hubungan yang mesra, kasih-sayang, dan perasaan diri. Dalam memenuhkan keperluan kasih sayang pula, manusia perlukan hubungan dengan insan lain. Kita semua pada asasnya ialah haiwan yang bersosial, iaitu kita perlukan kasih sayang daripada orang lain. Oleh itu, manusia ini sememangnya tidak boleh wujud bersendirian. Mereka berasakan diri dan emosi mereka berada di dalam keadaan yang tidak stabil menyebabkan tidak dapat menumpukan perhatian terhadap proses pembelajaran mereka. Situasi ini akan menimbulkan rasa tidak senang di kalangan pelajar terbabit dan merasakan diri mereka seolaholah tidak disukai, dihargai, atau tidak dipedulikan oleh guru mahupun kawan-kawan. Ekoran daripada itu keinginan, minat, juga kehendak atau motivasi mereka untuk belajar akan pudar dan lenyap.

\subsection{Kesan Gejala Berdua-Duaan \\ 2.2.1. Kesan Akademik}

Kebiasaannya prestasi bagi pelajar yang couple atau berdua-duaan ini adalah lemah. Ini kerana mereka yang terlibat dalam masalah ini hilang atau kurang fokus pada pembelajaran. Masa yang mereka ada untuk mengulangkaji pelajaran digunakan untuk meluangkan masa atau keluar berdua dengan pasangan mereka. Kerja rumah yang diberikan oleh guru semasa sesi persekolahan pula mereka buat ala kadar ataupun sekadar siap sahaja. Mereka lebih fokus pada hubungan yang dijalinkan berbanding pelajaran yang sememangnya sangat penting bagi seseorang pelajar. Kelakuan seperti inilah yang mendorong kepada prestasi pembelajaran mereka semakin lama semakin meresot dari hari ke hari. Akan tetapi, terdapat juga kes pasangan yang berdua-duaan yang mempunyai keputusan yang cemerlang dalam pelajaran tetapi hanyalah kes-kes terpencil sahaja.

\subsubsection{Kesan Tingkah Laku}

Menurut Kamus Dewan [7] tingkah laku bermaksud berbagai-bagai ragam dan berbagai-bagai tingkah laku. Manakalah menurut Milterbeger [8] tingkah laku bermaksud sesuatu yang dilakukan, cara untuk bertindak balas terhadap persekitaran. Menurut Beaker [9] pula, tingkah laku adalah apa yang kamu lakukan, cara berinteraksi atau beraksi dan bertindak balas terhadap persekitaran. Malahan, tingkah laku juga boleh mencakupi emosi dan mental seseorang itu. Teranglah daripada maksud-maksud yang ditulis disini menunjukkan bahawa tingkah laku mempunyai pengertian yang sangat luas.

Perubahan tingkah laku sememangnya akan berlaku terhadap setiap orang. Terutamanya perubahan tingkah laku yang melibatkan emosi dan mentaliti seseorang remaja dan pelajar sekolah. Tidak kiralah daripada pelajar sekolah menengah atau rendah. Salah satu perubahan tingkah laku ekstrem yang mudah dilihat adalah daripada kalangan remaja atau pelajar-pelajar sekolah yang berpasangan. Kita dapat melihat salah satu perubahan yang ketara antara remaja atau pelajar yang berpasangan adalah pelajar perempuan. Salah satu perubahan yang boleh dilihat adalah dari segi pemakaian mereka. Sebagai contoh, pelajar perempuan itu akan mula ingin untuk kelihatan cantik serta menawan untuk pasangan mereka. Meraka berbuat sedemikian untuk memastikan pasangan mereka tidak melihat perempuan lain.

Seterusnya, pelajar perempuan yang mempunyai pasangan juga selalunya akan mula mempunyai suatu perasaan seperti mengongkong dan rasa bahawa hubungan mereka tidak selamat. Sebagai contoh, pelajar perempuan itu tidak suka melihat teman lelakinya memandang orang lain dan merasakan diri mereka akan ditinggalkan jikalau mereka tidak kelihatan cantik atau menawan di mata teman lelaki mereka. Bagi pelajar lelaki pula, mereka akan mahu kelihatan maskulin dan bergaya di hadapan teman wanita mereka dan juga mempunyai perasaan yang sama seperti pelajar perempuan juga. Selain itu, apabila sudah lama bersama dan sudah tidak malu di antara satu sama lain. Remaja atau pelajar yang berpasangan ini akan mula berani untuk mula melakukan sesuatu pekara yang tidak senonoh terhadap satu sama lain yang mana melangar sisi hukum agama.

Perubahan tingkah laku ini boleh dikaitkan dengan teori perkembangan manusia yang dibuat oleh Sigmun Freud. Melalui huraian yang telah ditulis, pengkaji dapat melihat bahawa perubahan tingkah laku remaja atau pelajar ini lebih dipengaruhi oleh ID kerana mereka bertindak secara tidak matang, 
tidak logic, tidak bermoral iaitu menginkut nafsu dan naluri semata-mata tanpa memikirkan kesan atau akibat yang bakal dialami oleh mereka

\subsubsection{Kesan terhadap Diri Remaja}

Budaya berdua-duaan atau lebih dikenali sebagai budaya "couple" sangat memberi implikasi terhadap para pelajar masa kini. Pergaulan bebas antara lelaki dan perempuan ini secara tidak langsung adakalanya mengubah perangai individu tersebut kepada yang lebih baik mahupun kepada yang lebih buruk. Dari segi baiknya, sesetengah pelajar berusaha untuk menjadi yang terbaik dalam kalangan rakan mereka sendiri kerana ingin menambat hati pasangan masing- masing. Namun begitu, perasan cinta yang wujud dalam kalangan pelajar mampu meninggalkan kesan parut yang mendalam apabila berlakunya perselisihan faham antara dua pihak. Ini secara tidak langsung akan memberikan kesan negatif dari segi emosi terhadap diri remaja.

Antara kesan budaya "couple" dari aspek emosi dalam diri para pelajar ialah, menjurus kepada penyebabnya berlaku kemurungan. Gejala ini berlaku sekirannya hubungan cinta yang terjalin putus dipertengahan jalan atau wujudnya orang ketiga mahupun perselidihan faham dan sebagainya. Akibat daripada kekecewaan, ini akan memberikan tekanan kepada para pelajar seterusnya mengakibatkan berlakunya kemurungan. Berdasarkan penyelidikan Dr. Ajif Narib yang merupakan penyelidik di Universiti Perubatan Carolina Selatan, beliau menyatakan bahawa gejala kemurungan adalah seperti hilang selera makan serta hilang motivasi diri ialah perkara lazim yang sering dialami berikutan putus cinta. Kajian oleh saintis Amerika Syarikat itu juga mendapati kekecewaan putus cinta yang berlaku ke dalam diri wanita menyebabkan penurunan mendadak dalam aktiviti sel otak pada bahagian yang mempunyai kaitan dengan emosi, motivasi dan perhatian. Seterusnya, peningkatan kes bunuh diri turut menjadi kesan daripada budaya berdua- duaan dalam diri para pelajar. Hal ini berlaku atas faktor seseorang individu itu menhgarapkan sesuatu yang lebih dalam hubungan mereka namun berakhir dengan kegagalan.

Selain itu, kesan masalah berdua- duaan terhadap diri remaja ialah, peningkatan kes remaja lari dari rumah. Kes lari dari rumah merupakan masalh yang sukar dibendung kerana ia semakin berleluasa dalam kalangan pelajar. Perasaan atau ketaksuban perasaan cinta dalam kalangan pelajar menyebabkan mereka tenggelam dalam arus percintaan. Perkara akan menjadi lebih merosot apabila hubungan yang terjalin mendapat tentangan oleh keluarga. Hal ini secara tidak langsung mendorong para remaja untuk bertekad melakukan perbuatan lari dari rumah. Remaja perempuan pula mudah termakan dengan janji- janji manis lelaki hinggan sanggup lari dari rumah ingkar akan arahan ibu bapa demi untuk mengikut kekasih hati. Kementerian Pembangunan Wanita telah mengeluarkan statistik bahawa tiga punca utama remaja lari dari rumah ialah mengikut kekasih, pengaruh kawan, dan keinginan untuk bebas. Sebanyak 6,270 kes dicatatkan sejak 2004 hingga Mei tahun ini. Polis Diraja Malaysia (PDRM) menyatakan bahawa, terdapat kes remaja lari mengikut teman lelaki yang membabitkan remaja perempuan seawal usia 10 tahun, manakala peringkat umur 14 dan 17 tahun mencatatkan kes paling ramai iaitu 4,097 orang.

Teori yang boleh dikaitkan di sini adalah teori yang dikemukakan oleh Ivan Pavlov iaitu teori behaviourisme. Menurut laman web sesawang scribd yang ditulis oleh Eddliestaniselie teori ini mengatakan bahawa setiap rangsangan akan menimbulkan gerak balas. Gerak balas ialah apa sahaja tingkah laku yang timbul akibat daripada rangsangan. Manakala rangsangan pula adalah apa sahaja bentuk tenaga yang menimbulkan gerak balas pembelajaran boleh berlaku akibat kaitan di antara rangsangan dengan gerak balas. Rangsangan juga boleh dikaitkan dengan satu rangsangan yang lain untuk mendatangkan pembelajaran. Pembelajaran yang berlaku kerana perkaitan di namakan pelaziman manakala pembelajaran akibat dari perkaitan dua rangsangan di namakan pelaziman klasik.

\subsection{Langkah Gejala Berdua-Duaan \\ 2.3.1. Langkah Pihak Sekolah}

Pihak kaunselor dan guru-guru di sekolah juga harus terlibat secara aktif dan bergaul secara sihat dengan para pelajar. Perhubungan yang rapat antara guru dan pelajar akan menyebabkan pelajar merasa malu untuk mempamerkan tingkah laku yang sensitive. Susunan pelajar di dalam bilik darjah yang melibatkan jantina yang erbeza juga haruslah dikaji. Hal ini kerana, kesesuaian tempat duduk para pelajar memberikan impak yang besar dalam pergaulan antara pelajar. Pihak sekolah dan guruguru perlu menganalisa bentuk susunan yang bersesuaian dengan jumlah pelajar dan jantina mereka. 


\subsubsection{Langkah Ibu Bapa}

Tidak boleh dinafikan bahawa peranan ibu bapa sangat penting dalam mendidik emosi dan tingkah laku anak-anak. Ibu bapa merupakan insan yang paling terdekat dengan anak-anak atau remaja. Ibu bapa haruslah meluangkan lebih banyak masa dengan anak remaja mereka di rumah agar mereka rasa lebih disayangi. Menerapkan nilai-nilai kasih sayang yang mencukupi akan menyebabkan mereka tidak akan mencari kasih sayang dari pasangan yang berlainan jantina. Ibu bapa seharusnya sentiasa memberikan contoh dan tauladan yang baik untuk anak-anak dan pentingnya ibu bapa untuk mencari ilmu dalam setiap perkara supaya anak-anak terdidik dengan tingkah laku yang baik dan terpuji. Sekiranya ibu bapa mampu memainkan peranan dengan baik, maka masalah bercouple atau berduaduaan ini pasti dapat diatasi

Teori-teori yang boleh dikaitkan di sini adala hieraki yang keempat dalam teori keperluan Abraham Maslow iaitu, keperluan penghargaan kendiri yang menerangkan tentang bagaimana kita mahu berkuasa, sekurang-kurangnya ke atas diri kita sendiri. Pada masa yang sama, kita juga perlukan kekuatan, kebolehan, kepakaran serta kebebasan. Seterusnya manusia ingin dihormati, disanjungi dan kehendak status dalam hidup. Pelajar perlu mendapatkan perkara-perkara tersebut dengan bantuan pihak sekolah dan juga ibu bapa.

\section{Kaedah Kajian}

Dalam kajian ini, pengkaji telah menggunakan beberapa kaedah kajian iaitu termasuklah kaedah temubual dan kaedah perpustakaan bagi mendapatkan maklumat mengenai berpasangan atau berduaduaan dalam kalangan pelajar sekolah.

\subsection{Kaedah Temubual}

Temu bual didefinisi sebagai perbualan dua hala yang bertujuan untuk mengumpul maklumat kajian. Temu bual merupakan intraksi bersemuka antara penemu bual atau penyelidik dengan responden. Menurut Stewart [10] temu bual harus digunakan lebih daripada hanya sebagai alat pengumpulan maklumat; temu bual perlu bersifat reflektif dan dapat mencerminkan kehidupan dan keadaan sebenar mengenai sesuatu fenomena. Temubual boleh dikategorikan kepada tiga jenis iaitu temubual berstruktur, temubual semi-berstruktur dan temubual tidak berstruktur. Dalam kajian ini, pengkaji telah menggunakan temubual separa berstruktur iaitu orang yang ditemubual oleh pengkaji hanya menjawab soalan-soalan yang disediakan terlebih dahulu oleh pengkaji dan jawapan kepada setiap soalan tersebut adalah terbuka dan boleh dikembangkan oleh orang yang ditemubual Dalam kajian ini juga, pengkaji telah mendapatkan maklumat mengenai berpasangan atau berdua-duaan di kalangan pelajar sekolah dengan seorang guru wanita yang sedang menyambung $\mathrm{PhD}$ beliau di UPSI (Universiti Pendidikan Sultan Idris) dalam jurusan Biologi untuk mendapatkan maklumat tambahan dan lebih lanjut untuk kajian ini.

\subsection{Kaedah Penyelidikan Perpustakaan}

Pengkaji telah membuat rujukan di Perpustakaan Tuanku Bainun bagi mendapatkan maklumat tambhan tentang masalah yang sering dilakukan oleh pelajar di sekolah dan luar sekolah. Segala maklumat yang pengkaji peroleh ini adalah untuk menyokong dapatkan kajian pengkaji dan bahan rujukan yang menjadi rujukan pengkaji adalah seperti jurnal, artikel dan buku.

\subsection{Kaedah Menerusi Internet}

Pengkaji juga turut mencari maklumat di dalam internet untuk menambahkan lagi maklumat yang ada dan setiap maklumat yang di cari oleh pengkaji adalah soheh.

\section{Dapatan Kajian}

\subsection{Transkrip Temubual}

Penemubual : Boleh cikgu perkenalkan diri?

Responden : Assalamualaikum w.b.t nama cikgu Nurazila binti Hussin. Cikgu mengajar di Sekolah Menengah Kebangsaan Cina Bar. Pengalaman mengajar selama 4 tahu. Sekarang cikgu sedang menyambung pelajaran dalam bidang $\mathrm{PhD}$ dalam bidang Biologi. 
Penemubual : Adakah faktor pengguna media sosial merupakan faktor utama pelajar mudah berdua- duaan atau ber "couple" dengan menggunakan pelbagai aplikasi seperti whatsapp, instagram dan lain- lain?

Responden : Cikgu bersetuju kalau nak dikatakan faktor utama masalah ber "couple" atau berdua- duaan di sekolah adalah disebabkan media sosial. Dengan adanya media sosial, contonya yang paling digemari facebook, twitter instagram dan whatsapp akan memudahkan komunikasi antara satu sama lain.

Tiada masalah kalau gunakan untuk aktiviti yang betul, masalahnya bila komunikasi jadi terlalu senang, maka senanglah untuk membuat aktiviti yang tidak berfaedah. Contohnya, berkenalan, kemudiaanya bercouple, kemudian berdua- duaan. Untuk berkenalan dengan pelajar kelas lain pun senang. Search sahaja nama di media sosial terus dapat, kalau dibiarkan jadi tidak terkawal da terlalu bebas.

Penemubual : Adakah kurangnya perhatian daripada ibu bapa menyebabkan pelajar mencari kasih sayang di luar iaitu dengan bercinta?

Responden : Kurang perhatian dalam keluarga, cari kasih sayang di luar. Faktor ini merupakan faktor asaslah. Bila pelajar rasa sunyi, tiada tempat untuk meluah, suasana dalam rumah yang sunyi atau bosan, cara biasa untuk keluar dari perasaan sunyi dalam rumah adalah cari kasih sayang dekat luar. Dalam usia remaja, kasih sayang biasanya pelajar akan cari yang berlainan jantina supaya nak rasa disayangi, ada orang ambil berat dicampur jugak dengan perkembanagan fisiologi pelajar.

Penemubual : Pada pendapat cikgu, adakah faktor persekitaran merupakan punca masalah berduaduaan dalam kalangan pelajar?

Responden : Ya, faktor persekitaran adalah pengaruh utama contohnya pengaruh rakan sebaya. Tengok rakan sebagai pasangan, nak berpasangan juga. Nampak macam serono ada orang sayang boleh keluar dating, makan sekali, aktiviti bersama- sama.

Hilang matlamat jangka masa panjang untuk masa hadapan. Mungkin juga tiada contoh ikutan positif di sekeliling yang ada jadi tiada semangat dalamanunuk focus belajar danseterusnya berjaya.

Penemubual : Sepanjang pemerhatian cikgu di sekolah, pelajar tingkatan berapakah mula berpasang- pasangan?

Responden : Biasanya lelaki dalam umur 16- 17 tahun. Tingkatan 4- 5 yang paling rama, perempuan awal sikit dalam tingkatan 2 ke atas sebab biasanya abang senior yang akan mengorat pelajar- pelajar baru naik ke sekolah menengah. Tetapi sesame tingkatan dan kelas jugak pun ramai sebab senang dan selalu jumpa.

Penemubual : Pada pendapat cikgu, sejauh manakah pelajar ini menerima kesan dalam akademik masing- masing?

Responden : Kebiasannya prestasi bagi pelajar yang bercouple ini adalah lemah. Sebab hilangya focus pada pembelajaran. Masa yang ada untuk ulangkaji pelajaran digunakan untuk berdating, kerja rumah yang ada sekadar buat sekadar siap sahaja. Kalau berdating tapi prestasi bagus itu ada tetapi itu hanya kes terpecil sahaja.

Penemubual : Pada pendapat cikgu, apakah perubahan yang selalu kita boleh lihat pada tingkah laku pelajar ini?

Responden : Semestinya ada perubahan tingkah laku. Sebab bila adanya teman lelaki dan teman wanita ini, kalau perempuan itu hendak berlawa, nak nampak cantik, kadangkadang nak nampak seksi itu bahaya. Kalau lelaki nak nampak macholah. Kalau kes yang berat merek akan cari masa dan tempat yang jauh dari pandangan orang ramai yang mungkin akan membawa perlakuan- perlakuan yang tidak senonoh yang dilaran agama. 
Penemubual : Pada pendapat cikgu, apabila pelajar ini dikenakan hukuman atau pun diberikan nasihat adakah ia akan memberikan kesan mendalam dari aspek emosi dalam diri pelajar?

Responden : Hukuman it perlu sebab kalau dibiarkan akan berterusan dan tak terkawal. Cikgucikgu tidak akan mampu nak mengawal di luar sekolah tetapi sekurang- kurangnya dengan adanya hukuman di dalam sekolah, cikgu mampu untuk mengawalnya di dalam sekolah. selain memberi kesedaran kepada pelajar yang bermasalah dan juga kepada pekajar yangingin mencuba atau ada niat nak langgar peraturan sekolah.

Penemubual : Pada pengalaman cikgu, adakah usaha pihak sekolah yang mempertingkatkan aktiviti keagamaan memberi kesan dalam mengurangkan kes ini?

Responden : Perlu sentiasa dan berterusan. Aktiviti keagamaan ini akan memberikan ilmu kepada pelajar, atau memberi makanan rohani kepada pelajar. Sedikit sebanyak akan membuka hati dan minda pelajar akan tujuan sebenar belajar. Apa yng hendak dicapai, apa yang erlu dibuat, apa garis panduan yang perlu diikuti supaya hidup ini tidak tersebar dari tujuan hidup yang sebenar.

Penemubual : Pada pandagan cikgu, pakah peranan ibu bapa bagi memastikan masalah berduaduaan ini dapat dikurangkan?

Responden : Tidak boleh dinafikan peeranan ibu bapa sangat penting dalam mendidik emosi dan tingkah laku kepada anak- anak. Ibu bapa wajib sentiasa memberi contoh terbaik untuk anak- anak dan pentingnya ibubapa untuk memcari ilmu dalam setiap erkara supaya anak- anak terdidik dengan tingkah laku yang baik dan terpuji.

\subsection{Masalah Berdua-Duaan di Sekolah}

Melalui temubual tersebut masyarakat hari ini semakin mengutamakan kebebasan individu dalam segenap aspek kehidupan. Oleh sebab itu, amalan berpasangan yang dicetuskan oleh barat jelas kelihatan meresap ke dalam kehidupan masyarakat hari ini.

Hidup yang dipenuhi suka ria dengan melanggar batas-batas yang digariskan oleh agama dan nilainilai moral semakin menjadi-jadi. Lelaki dan wanita bergaul bebas tanpa had. Kehidupan masyarakat sebeginilah yang menyebabkan wujudnya kebejatan akhlak terutamanya kepada muda-mudi hari ini. Agama telah semakin jauh dari kehidupan dan hanya sebagai budaya dan adat, bukan dihayati dalam kehidupan.

Kita sudah sedia maklum bahawa pada zaman remaja, perubahan-perubahan biologi berlaku dengan amat pesat. Walau bagaimanapun, kita tidak pasti tentang sejauh mana pentingnya atau sekuat mana pengaruh biologi terhadap perkembangan aspek-aspek lain bagi remaja. Ahli-ahli psikologi yang berpegang pada teori ini percaya bahawa faktor hormon dan perubahan fizikal merupakan faktor yang berperanan dalam mempengaruhi perkembangan remaja.

Melalui sesi temubual bersama guru, terdapat beberapa faktor, kesan dan juga langkah yang boleh diambil demi menghapuskan atau mengurangkan masalah berdua-duaan ini di kalangan pelajar .

\subsection{Faktor-Faktor Masalah Berdua-Duaan di Kalangan Pelajar}

Berdasarkan temubual yang telah dijalankan terdapat tiga buah faktor utama yang menyebabkan masalah berdua-duaan ini berlaku antara pelajar sekolah. Media massa merujuk kepada pelbagai teknologi media yang bertujuan untuk mencapai sejumlah besar pengguna media melalui komunikasi massa. Teknologi melalui komunikasi dilakukan dengan cara yang pelbagai.

Pertama, faktor media massa yang sangat mendominasikan dunia sekarang. Tidak ada pelajar sekolah yang tidak mempunyai telefon bimbit dan masing-masing yang aktif di media sosial seperti whatsapp messenger, instagram, twitter, snapchat, facebook, dan juga tidak dilupakan tiktok. Media sosial tersebut ada kebaikannya masing-masing tetapi jikalau aplikasi ini tidak digunakan dengan baik, mereka akan menghadapi kesan kesannya.

Media massa seperti televisyen banyak mempengaruhi minda pelajar sekolah. Cerita-cerita tentang percintaan amat diminati oleh pelajar sekolah. Terdapat sebilangan pelajar yang meniru apa yang terdapat di televisyen. Justeru, tidak hairanlah berlakunya kes berdua-duaan di sekolah kerana mereka terpengaruh dengan media massa seperti ini. Walaupun bilangan pelajar yang meniru aksi watak- 
watak hero televisyen sedikit, tetapi perbuatan ini boleh menyusahkan ibu bapa dan pihak lain seperti sekolah.

\section{Perbincangan}

Dewasa ini, remaja sekolah menengah semakin ramai bercinta sehingga perlakuan cinta remaja jauh menyimpang sehingga akhirnya menimbulkan pelbagai masalah lain dalam kalangan remaja. Menurut Masroom [11] masalah sosial dalam kalangan pelajar perlu dieri perhatian serius kerana membabitkan golongan terpelajar. Kelakuan sumbang bukan sahaja mencemarkan imej sekolah ataupun institute pengajian tinggi malah sekor pendidikan tinggi Negara. Kita sudah sedia maklum bahawa pada zaman remaja perubahan biologi berlaku dengan amat pesat. Menurut Jaafar [12] ahli-ahli psikologi yang berpegang pada teori ini percaya bahawa faktor hormone dan perubahan fizikal merupakan faktor yang berperanan dalam mempengaruhi perkembangan remaja.

Semenjak tahun 1971 sehingga 2006, kes khalwat dan berdua-duaan adalah kes tertinggi daripada jenis kesalahan yang dilakukan iaitu sebanyak 3,818 daripadanya, 735 adalah merupakan kes khalwat dan berdua-duaan. Hasil perbincangan, penyelidik mendapati terdapat beberapa faktor yang mempengaruhi masalah berdua-duaan dalam kalangan pelajar. Antaranya ialah faktor media massa di mana golongan remaja mudah terdedah kepada banyak maklumat yang tidakerfaedah tanpa dipantau oleh ibu bapa. Golongan remaja pada hari ini telah dijangkiti ketagihan internet yang agak teruk (cybermania). Dunia tanpa sempadan, "Maklumat hanya di hujung jari" berdasarkan kenyataan tersebut, maklumat kini mudah untuk diperolehi tidak terbatas oleh jarak dan masa.

Selain itu,hasil perbincangan juga mendapati bahawa faktor ibu bapa juga turut mendorong kepada masalah bedua-duaan dalam kalangan pelajar. Menurut Ali [13] terdapat dalam kalangan ibu bapa tidak menunjukkan teladan yang baik kepada anak- anak, tidak sehaluan atau sefahaman di rumah dan sering berkelahi di hadapan anak- anak. Kepincangan dalam institusi kekeluargaan menyebabkan anak- anak merasakan kurang kasih sayang dan anak- anak secara tidak lazimnya akan berasa sunyi. Secara tidak langsung mereka akan mencari teman berlainan jantina untuk meluahkan masalah. Faktor persekitaran juga turut menyumbang kepada masalah berdua- duaan dalam kalangan pelajar. Kekecewaan terhadap keluarga ataupun persekitaran menyumbang kepada tingkah laku devian bagi mencapai maksud luahan perasaan [14]. Hasil perbincangan, didapati para pelajar mudah terpengaruh dengan rakan sebaya sehinggakan mereka tiada contoh ikutan yang positif. Menurut Bayanuni [15] mad'u atau masayarakat akan mudah terpengaruh dengan tindak tanduk seseorang yang dilihatnya sesuai.

Hasil kajian didapati masalah berdua- duaan ini yang jauh menyimpang menimbulkan pelbagai kesan dan masalah lain. Antaranya ialah kesan terhadap prestasi akademik. Menurut Shamsuddin[16] didapati pelajar yang bercinta telah merosot dengan ketara dalam pelajaran kerana mereka hilang focus terhadap pelajaran masing- masing. Selain itu, kesan terhadap tingkah laku pelajar di mana mereka cendurung untuk melakukan perkara yang tidak senonoh dan terlarang di sisi agama. Remaja akan kerap bersosial dan sering keluar malam bersama pasangan tanpa ikatan yang sah tanpa menumpukan perhatian dalam pelajaran. Dari segi pemakaian dan penggayaan mereka juga turut berubah. Hasil daripada perbincangan juga mendapati masalah bedua- duaan yang berleluasa meninggalkan kesan emosi terhadap pelajar. Gejala kemurungan akan berlaku dalam kalangan remaja sekirannya hubungan cinta yang terjalin terputus di pertengahan jalan. Apabila percintaan putus di tengah jalan, mereka akan mengalami gangguan emosi yang hebat sehingga berlaku kemurungan dan merosot pelajaran [17]. Gejala kemurungan ini akan turut meningkatkan kes bunuh diri dalam kalangan pelajar. Menurut Bartolomew \& Horowitz [18] keperluan untuk disayangi menyebabkan individu risau ditinggalkan dan sanggup melakukan apa sahaja untuk mendapatkan kasih sayang. Di samping itu, golongan remaja yang menghadapi masalah dalam hubungan akan berani lari dari rumah. Hal ini berlaku apabila hubungan mereka mendapat tentangan daripada keluarga. Namun begitu, kegagalan menangani hubungan menjadikan remaja dan individu awal dewasa terjebak dalam gejala sosial seperti perzinaan, kehamilan luar nikah, kelahiran anak luar nikah, pengguguran bayi, dan sebagainya.

Terdapat beberapa langkah yang telah diambil untuk membendung masalah berdua- duaan ini dalam kalangan pelajar di sekolah. Hasil perbincangan mendapati bahawa pihak sekolah memainkan peranan penting dalam menangani isu ini. Pihak sekolah haruslah memperbanyakkan aktiviti keagamaan, memberi makanan rohani agar mampu membuka hati dan minda pelajar. Pihak sekolah juga beperanan dalam menetapkan garis panduan dalam diri pelajar. Menurut Basri [19] peranan 
institusi sekolah adalah setaraf dengan peranan institusi kekeluargaan dalam bentuk mental dan rohani pelajar. Seterusnya, didikan daripada ibu bapa yang sangat mempengaruhi gaya perlakuan anak- anak dalam kata lain ibu bapa yang membentuk acuan anak- anak. Menurut Khalid [20] salah satu peranan penting bagi ibu bapa ialah kemahiran mendengar dan komunikasi dengan anak- anak. Ibu bapa haruslah setia mendengan masalah yang dihadapi anak- anak serta memberi contoh atau teladan yang baik. Perkara yang utama ialah penghayatan agama melalui contoh tauladan serta penerapan nilai agama dalam diri mereka.

Semua pihak haruslah bergabung sinergi untuk menangani masalah pergaulan bebas dalam kalangan pelajar sekolah. Hasil kajian dapat disimpulkan bahawa remaja bercinta mengikut fitrah diri yang ingin bercinta. Cinta sesama manusia dibenarkan dalam keadaan yang telah digariskan oleh syariat Islam. Cinta remaja lebih mudah membawa kepada kemungkaran sebagaimana dijelaskan dalam surah al-Israa' (17: 32) bermaksud "Dan janganlah kamu mendekati zina; sesungguhnya zina itu adalah suatu perbuatan yang keji dan suatu jalan yang buruk".

\section{Kesimpulan}

Kesimpulannya, masalah berdua-duaan atau berpasang-pasangan di sekolah semamamngnya berada di tahap yang membimbangkan. Ini adalah kerana masalah ini merupakan suatu masalah yang tiada satu sekolah pun terlepas daripadanya termasuklah sekolah menengah agama. Sekiranya perkara ini tidak dikawal ianya akan membawa kepada permasalahan gejala sosial remaja seperti lari rumah, buang anak, keruntuhan akhlak dan lemah dalam pelajaran. Dianggarkan secara purata 4,000 remaja perempuan hamil bawah 18 tahun dilaporkan setiap tahun berdasarkan statistik Kementerian Kesihatan Malaysia. Memetik statistik berkenaan, Timbalan Menteri Pembangunan Wanita, Keluarga dan Masyarakat, Hannah Yeoh berkata dari tahun 2012 hingga 2016, sebanyak 79,302 kes remaja perempuan hamil bawah umur 18 tahun telah dilaporkan.

Masyarakat seharusnya melakukan sesuatu dalam menangani masalah ini. Sebagai institusi yang diberi kepercayaan, pihak sekolah yang mewakili masyarakat mestilah melakukan sesuatu bagi mengelakan perkara ini daripada terus menular dan merosakkan generasi kepimpinan negara kelak. Pelbagai pendekatan seharusnya dilakukan untuk memastikan hal ini tidak terus berlaku. Hasil dapatan mendapati sekolah menengah agama swasta mempunyai paling kurang peratusan remaja bercinta $(<10 \%)$ berbanding sekolah menengah agama $(50 \%)$ dan sekolah menengah kebangsaan $(80 \%)$. Oleh itu setiap sekolah perlulah melihat pendekatan yang digunakan bagi sekolah yang mempunyai peratusan permasalahan yang rendah ini supaya dapat dilaksanakan di sekolah tersebut juga bagi mengurangkannya.

Media massa juga memainkan peranan yang sangat penting bagi remaja pada era ini yang seharusnya dkawal ketat kerana ianya mampu mendorong kepada pembentukan perilaku dan sikap agresif sehingga ada yang sanggup bertindak membunuh diri. Tindakan sedemikian boleh terjadi ekoran terlalu taksub, kecewa atau terpengaruh dengan kandungan di media sosial sehingga gagal membuat pertimbangan wajar. Contohnya, dalam kes pernah dilaporkan dalam akhbar di sebuah sekolah di Johor cuba membunuh diri selepas tidak tahan menjadi mangsa buli kenalan Facebooknya yang mahu mneyebarkan gambar lucah beliau di media sosial. Ini adalah salah satu kesan yang amat digeruni oleh setiap inidividu terutamanya remaja perempuan yang ianya bermula dari berpasangpasangan di sekolah.

Sebagai pihak yang paling rapat dengan remaja, ibu bapa memikul tanggungjawab yang sangat penting dalam menangani masalah ini pelbagai cara dan pendekatan yang boleh dilakukan oleh ibu bapa. Kasih sayang dan belaian yang secukupnya mampu mengurangkan atau mengelakkan anak-anak mencari kasih sayang dari individu luar. Sekiranya ibu bapa memainkan peranan dengan berkesan mereka mampu menyelamatkan anak-anak mereka dari terjerumus ke alam percintaan yang menghancurkan masa depan. Hal ini juga untuk memastikan generasi seterusnya dalam keadaan yang baik dan tidak menjejaskan genetiknya kelak. Oleh itu, ibu bapa seharusnya menjadi sahabat kepada anak-anak mereka tatkala anak-anak sudahpun meningkat remaja. Adalah sangat penting bagi ibu bapa untuk menjamin masa depan anak-anaknya agar tida terpesong dari landasan yang sebenarnya dengan terus memnuhi keperluan mereka sehingga mereka cukup matang untuk berfikir dan membuat keputusan sendiri secara wajar. 


\section{Rujukan}

[1] J. Piaget, Antara Tindakan dan Pikiran. Jakarta : PT.Gramedia,1988.

[2] R. Kayar, "Kelangsungan dalam Media dan Kesannya terhadap Tingkah Laku Agresif Pelajar." Tesis sarjana yang tidak diterbitkan, Universiti Teknologi Malaysia, Skudai, Malaysia, 2007.

[3] H. A. Tamuri, "Islamic Education teachers' perceptions of the teaching of akhlāq in Malaysian Secondary School," Journal of Moral Education, vol. 36, no. 3, pp. 371-386, 2007.

[4] A. Sarji, Penyiaran dan Pembangunan Pemaparan Nilai-Nilai Murni dan Tidak Murni melalui Penyiaran: Analisis Teori. Seminar Penyiaran dan Masyarakat. Universiti Putra Malaysia, Serdang. Malaysia, 2002.

[5] M. K. Ayub, Menangani Cabaran Membina Kecemerlangan Tamadun Ummah. Petaling Jaya: Budaya Ilmu Sdn. Bhd, 1994.

[6] A. Yahaya, and S. L. Jaafar, Membentuk Identiti Remaja. Pahang: PTS Publication \& Distributors Sdn. Bhd, 2005.

[7] Dewan Bahasa dan Pustaka. Kamus Dewan Edisi Ke-3. Kuala Lumpur: Dewan Bahasa dan Pustaka, 2005.

[8] R. G. Miltenberger, Behaviour Modification: Principles and Procedures. Toronto: Thomson Learning, 2001.

[9] M. L. Beaker, Democracy and Education. New York: Macmillan, 2001.

[10] C. J. Stewart, and W.B. Cash, Interviewing: Principles and practices. USA: McGraw Hill Company, 2000.

[11] M. N. Masroom, Persepsi Pelajar terhadap Isu-Isu Sosial: Satu Tinjauan di Universiti Teknologi Malaysia. Skudai: Universiti Teknologi Malaysia, 2004.

[12] J. L. S. Jaafar, Psikologi Kanak-kanak dan Remaja. Kuala Lumpur: Dewan Bahasa dan Pustaka, 1996.

[13] H. A. Ali, Salah Laku Sosial Remaja Masa Kini: Cabaran dan Penyelesaiannya dalam A.R. Abd Rahim, H. Sufean \& T. Jamaludin [eds]. Institusi Keluarga Menghadapi Cabaran Alaf Baru. Kuala Lumpur: Utusan Publication \& Distributors Sdn Bhd, 2006.

[14] N. B. A. Kadir, Memahami Masalah Sosial: Rangka Teoretikal Subjektif Mengikut Konteks. Kertas Kerja Seminar Kebangsaan Ke-3 Psikologi dan Masyarakat, Gejala Sosial dalam Masyarakat. Pusat Latihan KWSP. Bangi, Malaysia, 2004.

[15] A. Bayanuni, and A. Muhammad, Al-madkhal ilaa 'ilmi al da'wah Cetakan Kedua. Bairut: Muasasah al-Risalah, 2007.

[16] A. A. Shamsuddin, Hubungan Cinta dalam Kalangan Remaja: Satu Tinjauan Kes Sekolah Menengah Kebangsaan Sultan Abd Aziz Shah Kajang. Latihan Ilmiah. Universiti Malaya. Malaysia, 2005.

[17] M. Zainal, and S. A. Mohd, Panduan Mengurus Remaja Modern. Bentong: PTS Professional Publishing Sdn. Bhd, 2004.

[18] K. Bartholomew and L. M. Horowitz, Attachment Styles among Young Adults: A Test of a Four Category Model. Journal of Personality and Social Psychology, vol. 61, pp. 226-244, 1991.

[19] N. H. Basri, Masalah Disiplin Pelajar Satu Pendekatan dan Penyelesaian. Kuala Lumpur: Dewan Budaya, 2000.

[20] K. H. Khalid, Meneroka Alam Remaja. Kuala Lumpur: Nurin Enterprise, 1994. 